\title{
КЛІНІЧНИЙ ВИПАДОК ВДАЛОГО ЗАСТОСУВАННЯ ТЕНОФОВІРУ У ХВОРОГО НА ХРОНІЧНУ НDV-ІНФЕКЦІЮ 3 ВИРАЖЕНИМ ФІБРОЗОМ
}

\author{
Ужгородський національний університет, обласна клінічна інфекційна лікарня
}

\begin{abstract}
Хронічна HDV-інфрекція спричинює найтяжчі фрорми гепатиту з швидким орормуванням цирозу печінки та розвитком печінкової недостатності, а ефективні методи лікування перебувають на початковій стадії вивчення. Можливості проведення противірусної терапії значно обмежені за наявності протипоказань, особливо при вираженому фріброзі печінки. Наводиться приклад ефективного застосування тенофовіру у хворої на хронічну HDV-інфрекцію з фріброзом F4.
\end{abstract}

Ключові слова: хронічний гепатит $D$, лікування, тенофовір.

Вірус гепатиту D (HDV) належить до найменших вірусів, здатних інфікувати людину, спричинює найбільш тяжкі форми хронічного гепатиту - хронічний гепатит D (ХГД) [1]. На сьогодні у світі нараховується близько 15-20 млн осіб, інфрікованих вірусом гепатиту D [2, 3]. Україна відноситься до країн з низьким рівнем поширення цього вірусу [4].

HDV - дефектний вірус, який для своєї реплікації та експресії вимагає наявності допоміжного вірусу, а саме вірусу гепатиту В або іншого представника родини Hepadnaviridae [5]. Перебігати таке захворювання може лише у вигляді мікст-інсрекції, коли інфрікування відбувається одночасно двома вірусами, і суперінфекції, коли на фроні хронічного гепатиту В приєднується HDV-інфекція. У першому випадку існує висока ймовірність одужання (95-97 \%) [6], в окремих хворих можливий розвиток фульмінантного гепатиту [4, 5]. У другому випадку існує великий ризик швидкого прогресування захворювання з наступним розвитком цирозу $[7,8]$. Описаний ще один варіант перебігу - «Хелпер незалежна латентна інфекція». Вона виникає у пацієнтів після трансплантації печінки, внаслідок застосування специфічного імуноглобуліну (anti-HBs) з метою зменшення імовірності реінфікування трансплантата HBV. У даному випадку гепатоцити ізольовано можуть бути інфріковані HDV [7]. Хронічна HDV інфекція у 5-10 \% випадках має швидкий прогресуючий перебіг з формуванням печінкової недостатності від кількох місяців до 2-х років, у 15 \% - відносно спокійний перебіг, у 70-80 \% - розвивається цироз печінки впродовж кількох років, має стабільний перебіг з виникненням декомпенсації через 10-30 років [5].

На сьогодні етіотропна терапія хронічного мікстгепатиту B+D розроблена недостатньо [4, 5, 9]. Застосування лінійних інтерсреронів есрективне всього у $10 \%$ хворих [4], пегільованих - у 25-30 \% і часто вимагає тривалого застосування [10, 11]. Описані випадки, коли стійка вірусологічна відповідь отримана після 245 тижнів лікування [12]. Комбінована терапія пегільованим інтерфероном-альфра і адефовіром виявляється більш ефективною, але потребує подальшого спостереження для отримання віддалених результатів [1]. Застосування інгібіторів пренілірування та інгібіторів проникнення вірусу гепатиту видається найбільш есрективним, але знаходиться ще на початковій стадії клінічного дослідження [13-15].

HDV-інсрекція спричинює найтяжкі фрорми хронічного вірусного гепатиту, а ефективні методи лікування цієї страшної хвороби все ще знаходяться на початковій стадії вивчення [16].

Можливості проведення етіотропної терапії у хворих 3 хронічною HDV інфекцією значно обмежені при наявності протипоказань до призначення інтерферонів. Особливо зважено доводиться призначати лікування у хворих із вираженим фріброзом та цирозом печінки.

За таких умов, на нашу думку, цікавим буде випадок елімінації вірусу гепатиту D і B у хворої на хронічний мікст-гепатит B+D з вираженим фріброзом (F4) під впливом теносровіру.

Наводимо клінічний випадок, який спостерігався в Обласній клінічній інфекційній лікарні (ОКІЛ).

До кабінету амбулаторного прийому (КАП) ОКІЛ звернулась хвора С., 47 років, зі скаргами на загальну слабкість, знижену працездатність, періодичні неприємні відчуття, іноді болі у правому підребер'ї, пожовтіння склер.

Хворіє на хронічний гепатит В близько 10 років. Лікується періодично у гастроентеролога, гомеопата. 
Шість місяців тому звернула увагу на пожовтіння склер, звернулась по медичну допомогу. Лікування проводилося гомеопатом, без суттєвого покращення. Хвора стала відмічати незначну слабкість, швидку втомлюваність, знижену працездатність, що і спонукало ї звернутися до інфрекціоніста.

Анамнез життя не обтяжений. Строгу дієту пацієнтка не дотримує, зрідка вживає червоне вино. Має одну дитину, пологи одні, необтяжені, гемотрансфузій не отримувала, періодично лікується у стоматолога.

Хвора худорлявої статури. При огляді звертає на себе увагу слабо виражена жовтяничність шкіри, склер, слизової твердого піднебіння. Серцева діяльність ритмічна, тони ясні, гучні. АТ 110/70 мм рт. ст., пульс 76 за хв, задовільних властивостей. Грудна клітка нормостенічна. Перкуторно над легенями ясний легеневий звук, аускультативно - везикулярне дихання. Язик без нальоту, живіт бере участь у диханні, при пальпації помірно чутливий у правому підребер'ї. Печінка збільшена на 1,5-2,0 см, щільна, край помірно загострений, поверхня гладка. Селезінка збільшена на 1 см, помірно щільна. Симптом Пастернацького від'ємний з обох боків.

Результати обстеження на момент огляду (08.06.15 р.): загальний білірубін 34,5 мкмоль/л, прямий 19,7 мкмоль/л, аспартат-амінотрансфрераза (АсAT) 120,8 од./л, аланін-амінотрансфрераза (АлАТ) 150,4 од./л, ү-глутамілтрансфераза (ГГТ) 55 од./л, альбумін 33,6 г/л, загальний білок 79,4 г/л, лужна фросфратаза (ЛФ) 107 од./л, гепатит В ДНК ПЛР-кількісний - позитивний результат, $<7,5 \times 10^{2}$ копій/мл (аналітична чутливість методу 300 ко-

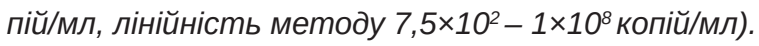

Встановлено діагноз: Хронічний гепатит В (ПЛР +) 3 помірною активністю, гепатоспленомегалія.

Рекомендовано провести додаткове обстеження.

Результати додаткового обстеження: загальний аналіз крові (ЗАК) 12.06.15 р.: гемоглобін 139 г/л, еритроцити 4,55×1012/л, лейкоцити 5,22×10\%/л, LY 30,4 \%, MI 11,6\%, GR 58,0 \%, тромбоцити 99×10\%/л, ШОЕ 9 мм/год. Біохімічне дослідження (12.06.15): загальний білірубін 50,5 мкмоль/л, прямий 18,7 мкмоль/л, АсАТ 134 од./л, АлАТ 160 од./л, ГГТ 39 од./л, альбумін 39 г/л, загальний білок 87 г/л, ЛФ 176 од./л. Маркери вірусних гепатитів (12.06.15): HBsAg - positive, $\mathrm{HBeAg}$ - negative, anti-HBeAg-IgG - positive, anti-HAV-IgM - negative, anti-HDV - positive. Запідозрений діагноз мікст-гепатиту $B+D$. Ультразвукове обстеження органів черевної порожнини 12.06.15 р. Печінка виступає 3-під реберного краю за рахунок вісцероптозу, контури хвилясті, в розмірах не збільшена. Паренхіма неоднорідна, середньо-, крупнозерниста, підвищеної ехогенності, судинний малюнок дещо деформований; внутрішньопечінкові протоки не розширені. V. portae розширена до 1,4 см. Жовчний міхур розмірами 6,6×4,8 см, дефрормова- ний, контури чіткі. Підшлункова залоза не потовщена, дещо неоднорідної структури, контури хвилясті, чіткі. Селезінка збільшена, розмірами 15,3×5,2 см, структура не порушена, контур рівний, межі чіткі, розташована типово. V. lienalis 0,9 см. При проведенні фрібротесту (20.06.15 р.) встановлено фріброз 4-го ступеня (F4), активність 3-го (АЗ). Одноразово було проведено дослідження на системні захворювання, яке виявилося позитивним (ANA-Screen, ДНК двоспіральна, антитіла IgG $46 \mathrm{IU} / \mathrm{ml}$ (N - 10). Додаткове обстеження на ПЛР (02.07.15р.) якісно підтвердило наявність РНК вірусу ГD. На основі отриманих даних встановлений діагноз: «Хронічний гепатит В з дельта-агентом (ПЛР ДНК HBV (+) і PHK HDV $(+))$, F4, A3, гепатоспленомегалія, тромбоцитопенія». Враховуючи стадію фріброзу (F4), наявність антитіл до двоспіральної ДНК, хворій запропоновано тенофовір у добовій одноразовій дозі 300 мг впродовж 24 місяців [17].

При контрольному відвідуванні КАП ОКІЛ (28.07.15 р.) стан хворої дещо покращився: менше турбують загальна слабкість, знижена працездатність. В даних об'єктивного обстеження суттєвої динаміки не виявлено. Лабораторне обстеження: ЗАК (28.07.15 р.): гемоглобін 147 г/л, еритроцити 4,48×10²/л, лейкоцити 6,34×10\%, LY 22,1 \%, MI 8,4 \%, GR 69,5\%, тромбоцити 177×10\%, ШOE 22 мм/год. Біохімічне дослідження (28.07.15 р.): загальний білірубін 46,1 мкмоль/л, прямий 27,1 мкмоль/л, АлАТ 152 од./л, ГГТ 39 од./л, альбумін 47 г/л, загальний білок 76 г/л.

28.09.15 р. стан хворої ближче до задовільного. Скарги на незначні неприємні відчуття у правому підребер'ї. Шкіра майже звичайного кольору, склери з натяком на жовтяничність. Легені і серце в межах норми. Язик чистий, вологий. Живіт при пальпачії неболючий. Печінка +1,5 см нижче реберної дуги, щільної консистенції, край загострений, поверхня гладка. Селезінка збільшена на 1 см, щільно-еластичної консистенції.

Лабораторні показники: ЗАК-гемоглобін 145 г/л, еритроцити 4,40×1012/л, лейкоцити 5,45×10\%/л, LY 28,3\%, MI 7,9\%, GR 63,8 \%, тромбоцити 145×10\%/л, ШОЕ 23 мм/год; біохімія крові - загальний білірубін 37,2 мкмоль/л, прямий 14,8 мкмоль/л, АсАТ 147 од./л, АлАТ 142 од./л, ГГТ 32 од./л, альбумін 29, 9 г/л, загальний білок 72 г/л.

На 110-й день лікування тенофровіром (01.10.15 р.) хвора пройшла повторне дослідження крові на PHK HDV і ДНК HDV методом ПЛР, яке виявилося негативним. Стверджувати про повне зникнення вірусів з крові наразі не $\epsilon$ можливим через досить низьку аналітичну чутливість дослідження (255 копій/мл). Однак під впливом лікування тенофровіром у даної хворої досягнуто значного зменшення кількості ДНК і РНК вірусних гепатитів, а можливо і повного зникнення. Зменшення або відсутність вірусу $\epsilon$ прогностично доброю ознакою у перебігу хронічних 


\section{КОРОТКІ ПОВІДОМЛЕННЯ}

гепатитів і фрормуванні цирозу печінки [18]. Тривалість досягнутого терапевтичного ефректу потребує подальшого спостереження за хворою.

Таким чином, тенофовір можна рекомендувати у лікуванні хворих на хронічну HDV-інфекцію, особливо за наявності протипоказань до застосування інтерферонотерапії.

\section{Література}

1. Heidrich B. Treatment options for hepatitis delta virus infection / B. Heidrich, M.P. Manns, H. Wedemeyer // Curr Infect. Dis. Rep. 2013. - Vol. 15, N 1. - P. 31-38.

2. Delta-infection and suppression of hepatitis $B$ virus replication in chronic HBsAg carriers / [K. Krogsgaard, P. Kryger, J. Aldershvile et al.] // Hepatology. - 1987. - N 7. - P. 42-45.

3. Acute and chronic hepatitis delta virus infection: direct or indirect effect on hepatitis B virus replication? / [P. Farci, P. Karayiannis, M.E. Lai et al.] // J. Med. Virol. - 1988. - N 26. - P. 279-288.

4. Порохницький В.Г. Вірусні гепатити / В.Г. Порохницький, В.С. Топольницький. - К.: Книга-плюс, 2010. - 480 с.

5. Учайкин В.Ф. Инфекционная гепатология: руководство для врачей / В.Ф. Учайкин, Т.В. Чередниченко, А.В. Смирнов. - М.: ГЕОТАР-Медиа, 2012. - 640 с.

6. Hepatitis B Virus Replication in Acute Hepatitis B. Virushepatitis Delta Coinfection and Acute Hepatitis Delta Superinfection / [I.J. Genescal, R. Jardi, M. Butti et al.] // Hepatology. - 1987. - Vol. 7, N 3. - P. 569-572.

7. Influence of delta infection on severity of hepatitis B / [A. Smedile, P. Farci, G. Verme et al.] // Lancet. - 1982. - Vol. 2, N 8305. - P. 945-947.

8. Chronic hepatitis incarriers of hepatitis B surface antigen with intrahepatic expression of the delta antigen. An active and progressive disease unresponsive to immunosuppressive treatment / [M. Rizzetto, G. Verme, S. Recchia et al.] // Ann. Intern. Med. - 1983. - Vol. 98, N 4. - P. 437-441.

9. Шиффф Ю.Р. Болезни печени по Шифрфу / Ю.Р. Шифф, М.Ф. Соррел, У.С. Мэддрей: пер. с англ. В.Т. Ивашкина, Е.А. Климовой, И.Г. Никитина, Е.Н. Широковой. - М.: ГЕОТАР-Медиа, 2010. - 398 с.

10. Maraolo A. Letter: the potential success of long-term therapy of chronic delta hepatitis with peginterferon alfa / A. Maraolo, F. Minervini, G. Tosone // Aliment Pharmacol The. - 2015. - N 41. - P. 595.

11. Long-term therapy of chronic delta hepatitis with peginterferon alfa / [T. Heller, Y. Rotman, C. Koh et al.] // Aliment Pharmacol The. 2014. - N 40. - P. 93-104.
12. Resolution of chronic delta hepatitis after 12 years of interferon alfa therapy / [D.T. Lau, D.E. Kleiner, Y. Park et al.] // Gastroenterology. - 1999. - N 117. - P. 1229-1233.

13. Understanding hepatitis virus dynamics and antiviral efficacy of the prenylation inhibitor lonafarnib / [L. Canini, C. Koh, S.J. Cotler et al.] // Hepatology. - 2014. - N 60. - P. 32A-91A.

14. Prenylation inhibition with lonafarnib decreases hepatitis $D$ levels in humans / [C. Koh, C. Yurdaydin, S. Cooper et al.] // Hepatology. - 2014. - N 60. - 92A-196A.

15. A proof-of-concept Phase 2a clinical trial with HBV/HDV entry inhibitor Myrcludex B / [P. Bogomolov, N. Voronkova, L. Allweiss et al.] // Hepatology. - 2014. - N 60. - P. 1267A-1290A.

16. Wedemeyer $\mathrm{H}$. Epidemiology, pathogenesis and management of hepatitis D: update and challenges ahead / $\mathrm{H}$. Wedemeyer, M.P. Manns. - Nat. Rev. Gastroenterol. Hepatol. - 2010. - N 7. P. 31-40.

17. Инфекционные болезни. Фармакотерапия / Под ред. Л.В. Мороз. - К.: Доктор-Медиа, 2011. - 440 с.

18. Абдурахманов Д.Т. Возможен ли регресс фриброза печени при хроническом вирусном гепатите? / Д.Т. Абдурахманов, М.В. Северов // Клиническая фрармакология и терапия. - 2011. № 20 (1). - C. 21-25.

\section{CASE OF SUCCESSFUL ADMINISTRATION OF TENOFOVIR IN PATIENTS WITH CHRONIC HDV-INFECTION WITH SEVERE FIBROSIS}

\section{A.I. Kohutych}

SUMMARY. Chronic HDV-infection most often occurs in severe forms of hepatitis with rapid formation of liver cirrhosis and development of liver failure, but the effective treatment is at an early stage of development. The possibility of antiviral therapy significantly limited if there are contraindications, especially in distinct liver fibrosis. The article is an example of effective use of tenofovir in patients with chronic HDV-infection with fibrosis F4.

Key words: chronic hepatitis D, treatment, tenofovir.

Отримано 10.11.2015 p. 